\title{
Capitalism, Christianity, and Slavery: Jesuits in New Spain, 1572-1767
}

\author{
John Tutino \\ Georgetown University, Washington, DC, USA \\ tutinoj@georgetown.edu
}

\begin{abstract}
The Jesuits arrived in New Spain in the 1570 s and soon became participants in a dynamic world of silver capitalism at the center of the early modern global economy. They launched money-making enterprises to sustain their missions, churches, and schools (colegios) that relied upon enslaved African producers alongside indigenous workers in complex labor arrangements. The diversity of labor at the Jesuit-run Santa Lucía and Xochimancas estates contrast with the heavier reliance on enslaved African labor at Jesuit sugar plantations in Brazil. The article analyzes a key eighteenth-century Jesuit text, the Instrucciones a los hermanos jesuitas administradores de haciendas, to show how the Jesuits in New Spain conceived of their management of enslaved people and negotiated the contradictions between the spiritual and secular challenges of the boom era of silver capitalism.
\end{abstract}

\section{Keywords}

New Spain - slavery - silver - capitalism - enslaved people - labor management schools

Founded in 1540, the Jesuits entered a world of change. Europeans debated the meanings and politics of Christianity as their seafaring merchants sought new worlds of profit. The prospects of profit and the truths of Christianity became linked, often uncomfortably, as merchant imperialists and Christian clergy engaged a world of diversity. Monarchs pursued power linked to claims of divinely sanctioned justice. Traders sought gain. Clergy_including Jesuits_-dreamed of a world shaped by justice and 
pursuits of a common good. ${ }^{1}$ When Jesuits came to the city of Mexico in the 1570 s, they aimed to promote Christian education in a center once capital of a militarized Mexica (Aztec) regime, now the pivot of a commercializing kingdom of New Spain. They would live and work in a region rapidly becoming pivotal to a monetizing world economy-a center of silver capitalism. Contradictions were inevitable. ${ }^{2}$

The Jesuits became pivotal participants in global encounters that remade the world. ${ }^{3}$ They were active in Portuguese Brazil and India from the 155 os. ${ }^{4}$ In the 1570s, they were in Mexico City; by the 1580s, they were in Lima, the center of Spanish South America. Across the Americas, they focused on providing education in Catholicism. Building urban colegios for the sons of Europeans seeking power and profit, Jesuits aimed to promote justice and the common good. They founded separate schools for the sons of native lords adapting to European ways. And they forged missions to promote Christianity and community among independent native peoples struggling to carry on in a world of change-from the Guaraní of far South America to the Yaqui on the Pacific coasts of New Spain. The goal was to promote Christian truth, seek justice, and promote the common good. Yet to fund education and mission work, Jesuits had to engage a commercializing world in which enslaved Africans were key producers.

This essay focuses on Jesuit participations in New Spain's silver capitalism, including their limited yet pivotal reliance on enslaved African producers. It keeps Brazil's founding plantation capitalism in view, to highlight key contrasts in Jesuit participations in New World slavery. It emphasizes a Jesuit understanding of Christianity and slavery in eighteenth-century New Spain, the boom era of silver capitalism thanks to the survival of a key Jesuit text. $^{5}$ The Jesuits' grappling with capitalism, Christianity, and slavery in New Spain was part of a larger culture of silver capitalism —and of early global

1 This perspective is featured in a coming study of the Jesuits and the Guaraní: Brian Owensby, Seeking the Land-Without-Evil in the New World of Gain: Toward a Global History of Moral Economy (Stanford, CA: Stanford University Press, forthcoming), especially Chapter 2.

2 On silver capitalism, see John Tutino, Making a New World:Founding Capitalism in the Bají and Spanish North America (Durham, NC: Duke University Press, 2011) and The Mexican Heartland: How Communities, Shaped Capitalism, a Nation, and World History, 1500-1700 (Princeton, NJ: Princeton University Press, 2018).

3 John W. O'Malley, The First Jesuits (Cambridge, MA: Harvard University Press, 1993).

4 Ananya Chakravarti, The Empire of Apostles: Religion, accomodatio, and the Imagination of Empire in Early Modern Brazil and India (New Delhi: Oxford University Press, 2018).

5 Instrucciones a los hermanos jesuitas administradores de haciendas (manuscrito mexicano del siglo XVIII), with Prologue and notes by François Chevalier (Mexico City: Universidad Nacional Autónoma de México, 1950) [hereafter IHJ]. 
capitalism - that pursued profit while searching for Christian truth, justice, and community. It is a history of contradictions-like most histories.

\section{Many Americas, Diverse Jesuit Engagements: Brazil First}

Europeans arriving in the sixteenth-century Americas encountered diverse societies. The imperial Inca domain that spanned the Andes and the regional states such as the Mexica in Mesoamerica had built military power on cultivating communities, not unlike societies in Asia and Europe. Still, large areas of the hemisphere along Atlantic coasts and in vast interiors saw people living free of concentrated state powers - diverse, independent, often mobile, hunting, gathering, and cultivating peoples who also warred with neighbors. The Guaraní and the Yaqui were prime yet very different examples.

State and state-free societies (with endless variations) faced European newcomers who imagined "conquests" and rights to rule, pursued gain in tribute and trade, and believed they could force "conversions" to Christianity. While learning that all these presumptive impositions came laden with challenges, they imported Old World diseases, smallpox and more, that killed native peoples: radically cutting populations, assaulting prevailing ways of rule and social integration, questioning established truths. As socially and culturally diverse peoples faced pandemic death and European presumptions, the newcomers learned that there were diverse Americans - and that none would simply submit to their demands and dreams. In diverse domains facing dissolution, conflict, and reconstruction, Europeans had to negotiate to claim rule and profit, while Jesuits and others promoting new truths found people willing to listen and respond-yet rarely ready to "convert" in any simple or subordinate way. ${ }^{6}$

Jesuits first faced the challenge of the Americas in coastal Brazil. From the 1550s, they focused on bringing Christianity to the Tupí and others living as cultivators who had not known life under state powers. After the first contacts of 1500, Portuguese mariners traded metal wares for brazilwood, a valued red dye cut by independent natives. By mid-century, the Tupí lost interest in the trade (needing only so many axes, knives, and bowls) while Portuguese planters backed by Genoese financiers began to see sugar as a source of profitable exports to Europe. Small groups of enslaved Africans drawn from

6 See Alfred Crosby, The Columbian Exchange: Biological and Cultural Consequences of 1492 (1972; reprint, New York: Cambridge University Press, 2003), Steve Stern, Peru's Indigenous Peoples and the Challenge of Spanish Conquest: Huamanga to 1640 (Madison: University of Wisconsin Press, 1982); and Tutino, Mexican Heartland, Chapters 1 and 2. 
Portuguese Atlantic islands provided a core of skilled and supervisory workers. Native Brazilian captives, forced into bondage backed by claims they refused Christianity, provided permanent labor. Meanwhile, Jesuits (backed by the crown) drew other natives into villages, offering baptism, salvation, and protection from bondage. They also sent crews of villagers to work seasonally cutting cane, hard labor that earned income for mission villages. Jesuits protected their charges from bondage and sent them to work in the cane, tying their Christianizing mission to Brazil's protean sugar economy.

The experiment proved the profitability of sugar in emerging Atlantic markets-and the deadly impact of imported diseases. As sugar became profitable, the native workforce all but vanished, the inevitable outcome of being drawn to regular contact with Europeans, Africans, and the Old World plagues they carried. Portuguese officials and planters began to write home lamenting that Brazilian natives were useless workers, whether bound or free: as soon as they learned the work, they died. ${ }^{7}$

Enabled by sugar, Portuguese planters and their Genoese backers turned to drawing growing numbers of enslaved Africans to labor in an expanding export economy. After 160o, they consolidated a plantation model tying sugar production to the labor of large communities of enslaved Africans - a model that would shape Atlantic America for centuries. In time, Jesuits joined the new economy, owning plantations worked by bound Africans to sustain colleges for the sons of prosperous Portuguese Brazilians. ${ }^{8}$ In Brazil, the first Jesuits in the Americas joined in the foundation of plantation capitalism - a profitable means to sustain their Christian work.

When they arrived in New Spain in the 1570s, Jesuits faced a different New World. Iberians had come in 1519, engaging an inland world of militarized states built upon cultivating communities. Before Jesuits arrived, the people of Mesoamerica had faced waves of epidemics that drove populations down by more than half, enabling Spanish rule yet making the gains of rule ever less certain. Then in the 1550s, Ming China, the largest polity and economy in the world, turned to a silver standard. A new economy focused on silver rose in Spanish America, drawing Europeans, diverse indigenous peoples, and enslaved Africans into new ways of production and cultural change. ${ }^{9}$ Profit-seeking gain

7 Stuart Schwartz, "Indian Labor and New World Plantations: European Demands and Indian Responses in Northeastern Brazil," American Historical Review 83, no. 1 (1978): 43-79.

8 On the Jesuits and the development of sugar in Brazil, see Stuart Schwartz, Sugar Plantations in the Formation of Brazilian Society: Bahia, 1550-1835 (New York: Cambridge University Press, 1985).

9 The Spanish Andes centered on the viceroyalty at Lima and driven economically by the mines at Potosí also saw Jesuits take key economic roles to sustain their educational activities. On silver, see Kris Lane, Potosi: The Silver City that Changed the World (Oakland: University of 
and Christian goals of justice jostled together in domains radically distinct from the coastal plantation regions rising in Brazil. Both rapidly commercialized. Both set foundations for a new capitalist world. Both drew enslaved Africans to work for others' profit. Yet Portuguese Brazil and Spanish America, including New Spain, took opportunities for gain and incorporated enslaved Africans in distinct ways.

Making New Spain: From Mesoamerica to Silver Capitalism

In 1500, the Mesoamerican world (ranging from regions now central Mexico through Guatemala) included at least twelve million people, and perhaps as many as twenty-four million. It was a domain of warring states taking tributes from cultivating communities (in that, not unlike Europe). Deep in interior highlands, the island city of Mexico-Tenochtitlan had grown to over two-hundred thousand people, the ruling center of a Mexica (Aztec) regime fighting to expand east and south, while blocked to the west by a powerful Tarascan regime and to the north by independent, mobile, state-free Chichimecas. ${ }^{10}$

In 1519, Fernando Cortes (1485-1547) blustered into that world at war with a few hundred men, iron weapons, and links to Europe. They fought when challenged, built alliances with the Mexica's enemies, then entered the capital to meet with Moctezuma (1466-1520), the reigning Mexica sovereign. Surrounded and isolated, the Iberians provoked conflict, faced a deadly siege, and took flight in the famous noche triste (sad night [to Europeans]). Just over a hundred survivors escaped to recover among Tlaxcalan allies. Then in 1520, smallpox arrived from the Old World, striking people with no historic immunities. A third of the people died in an epidemic that killed native lords and priests, warriors and producers, men and women, adults and children in unimaginable devastation. Smallpox cleared the way for the

California Press, 2019). On the dispersed activities of the Jesuits, see Nicholas Cushner, Lords of the Land: Sugar, Wine, and Jesuit Estates of Coastal Peru, 1600-1767 (Albany: State University of New York [henceforth SUNY] Press, 1980); Cushner, Farm and Factory: The Jesuits and the Development of Agrarian Capitalism in Colonial Quito, 1600-1767 (Albany: SUNY Press, 1983); and Cushner, Jesuit Ranches and the Agrarian Development of Colonial Argentina, 1650-1767 (Albany: SUNY Press, 1984).

10 This synthesis derives from Tutino, Mexican Heartland: Chapter 1 offers a comparative exploration of the origins of silver capitalism in the Andes, the heartland around Mexico City, and the Bajío. Chapter 2 details the first two centuries of mining and social reconstruction in the heartland - the scene of the Jesuit activities focused on here. 
fall of the Mexica regime in 1521 to forces Cortes claimed to lead yet were overwhelmingly Mesoamerican. ${ }^{11}$

The result was not conquest, but a half century of dissolution, as smallpox recurred in waves while other Old-World maladies-plague, measles, typhus, and more-accelerated the dying. By all accounts, more than half of all Mesoamericans had succumbed by $155^{\circ}$, ninety percent by the early 16oos. Amid the devastation, Cortes proclaimed the sovereignty of Charles $\mathrm{V}$ (1500-58; r.1519-56) and the truth of Catholicism. He awarded encomiendas to Iberian allies, granting rights to take tribute goods and labor service from surviving native communities. Such grants, however, required the collaboration of native lords to collect tributes and organize labor in communities that continued to cultivate, trade, and work in Mesoamerican ways. While Iberians reached for power, native lords remained essential to a society still grounded in indigenous ways of rule and production. The coming of a high court to mediate disputes early in the 1530, followed by a viceroy to represent the king in 1535, revealed aspirations to power more than effective rule as population and production plummeted all around.

From the start, Cortes aimed to bring Christianity to Mesoamericans-as truth and as legitimation for claims to power. When native lords allied with Iberian intruders, they accepted baptism and Christian names. Iberians imagined conversions and subordination; locals saw religiously sanctioned alliances. Mutual misunderstandings of convenience were facilitated as Christians knew that there was one Truth: accepting God meant rejecting all false gods. Mesoamericans, in contrast, had long worked to accumulate divine allies and protectors - adding a new power to reinforce worldly rule or to assist with cultivation or curing did not mean rejecting old forces of long service.

Cortes and the emerging Iberian regime were equally committed to bringing Christian truth to the cultivating communities that sustained everything. Franciscans came in the 1520 os to the Mexica heartland; Dominicans and Augustinians arrived soon after and spread to distant communities. They baptized en masse, preached and persuaded with energy. By mid-century, as the population plummeted, growing numbers of survivors saw themselves as Christian in a turn long labeled a "spiritual conquest" - implying conversions. Yet friars were few, often working alone or in pairs among thousands in rural zones. And while native survivors accepted baptism, friars lamented failures to create "true Christians." Indigenous peoples baptized children, honored the saving power of Christ, and welcomed the promise of assistance from diverse

11 Crosby, Columbian Exchange. 
saints and the Virgin Mary. Yet beyond baptism and perhaps marriage, the sacraments were of little interest; $\sin$ and penance seemed alien concepts. ${ }^{12}$

Mesoamericans built indigenous Christianities—as so many Europeans and others had done before. They reconstructed truths to understand and adapt to a world of unprecedented change. Most unprecedented was the dying. For Mesoamericans from $15^{20}$ to 1580 , death was the single most pervasive reality of life. Unknown diseases came in devastating waves; old divinities offered neither explanation nor cure. The gift of Christianity was universal access to salvation after death. Disease-driven death not only was the primary force enabling Europeans to establish power in Mesoamerica, the dying was also a principal stimulus to the near universal turn to Christianity among Mesoamericans-on their own terms.

By 155 o, the Mesoamerican world faced rapid dissolution. Iberians claimed to rule, while Mesoamerican survivors clung to life, reaching for new truths in times defined by death and depopulation. Europeans might consolidate rule, but to what end? The tributes and labor gangs delivered by encomienda rights disappeared along with the populations that provided them. The $1542 \mathrm{New}$ Laws prohibited the enslavement of native peoples and ended the inheritance of encomiendas that became ever less valuable as the population vanished. Indigenous people faced desperation and death-and turned to Christianity in a deluge of plagues. Iberians might consolidate power, but their chances for wealth appeared to vanish along with the people of the once powerful and productive Mesoamerican world they aimed to rule.

Then, early in the 155 os, the emperor of Ming China, the largest, most populous, most productive domain in the world, decreed that only silver would serve as money for taxes, large transactions, and international exchange. ${ }^{13}$ Within the decade, global demand for silver soared. Silver mining became the economic engine of Spain's Americas. ${ }^{14}$ As Spanish rule set in and native people died, the stimulus of Chinese demand for silver set New Spain on a course toward commercial development—constrained by a vanishing population. ${ }^{15}$

12 The classic study is Robert Ricard, The Spiritual Conquest of Mexico, trans. Lesley Byrd Simpson (Berkeley: University of California Press, 1966). A new view emphasizing the impact of death and disruption is in Jennifer Scheper Hughes, Biography of a Mexican Crucifix: Lived Religion and Local Faith from Conquest to the Present (New York: Oxford University Press, 2009).

13 Dennis Flynn and Arturo Giráldez, "Born with a Silver Spoon: The Origins of World Trade in 1571, Journal of World History 6, no. 2 (1995): 201-21.

14 On Spanish South America, see Lane, Potosí.

15 This is the emphasis of Tutino, Making a New World. 
There had been precedents. Early encomenderos had sent tribute work gangs to pan for gold along streams in southern Mesoamerica. The yield helped pay for early Iberian incursions, but surface deposits quickly panned out. ${ }^{16}$ Cortes and a few allies built sugar estates around Cuernavaca, in lowlands just south of Mexico City, from the 1530s. They drew enslaved Africans skilled in sugar making from Atlantic islands to serve as supervisors and technicians, while drawing villagers subject to encomienda drafts to clear fields, then to plant and harvest cane. The produce served emerging Hispanic markets in Mexico City, introducing commercial cropping and enslaved African producers into a still primarily Mesoamerican world. ${ }^{17}$

Silver, too, was mined early at Taxco in uplands west of Cuernavaca. It had artistic uses among Mesoamericans, who did not know the metal as money. When they saw how Europeans valued silver, local lords mobilized native workers to dig surface ores they refined by smelting with fire, selling the silver to Iberians linked to Atlantic markets. Europeans complained that natives ruled production and labor and took most profit. Iberians took what they could and introduced a few enslaved Africans to serve as smiths making metal tools and muleteers transporting supplies and silver. They also profited a bit, to their masters' lament. ${ }^{18}$

Early production of gold, sugar, and silver set commercial precedents in a Mesoamerica facing depopulation. Then in the 1550 s, the stimulus of Chinese demand made silver the leading sector of a commercializing New Spain, energizing a social reconstruction that aimed to sustain mines and urban centers by stabilizing native communities and building Hispanic commercial estates.

Mining quickly soared at Taxco and at Pachuca, northeast of Mexico City. There, Bartolomé de Medina (1497-1585) famously adapted the patio process (developed in German-speaking lands to use mercury to refine mid-grade ores) to New World conditions. Set between two mining centers, the once Mexica capital city revived as the administrative, judicial, financial, and commercial pivot of New Spain and its silver economy. ${ }^{19}$ Among the leading mine operators at Pachuca was Alonso de Villaseca (1500-80). Arriving in the 1540s, he

16 See José Miranda, La función económica del encomendero en los orígenes del régimen colonial, 1521-1531 (Mexico City: Universidad Nacional Autónoma de México, 1965).

17 Ward Barrett, The Sugar Hacienda of the Marqueses del Valle (Minneapolis: University of Minnesota Press, 1965).

18 Early silver mining at Taxco is revealed in José Enciso Contreras, Taxco en el siglo XVI: Sociedad y normatividad en un real de minas novohispano (Zacatecas: Universidad Autónoma de Zacatecas, 1999).

19 On the city, see Barbara Mundy, The Death of Aztec Tenochtitlan, the Rise of Mexico City (Austin: University of Texas Press, 2015). 
never gained an encomienda, never depended on the dissolving Mesoamerican world of tribute extraction. He invested in silver mines and in commercial estates between the capital and the mines. He profited by mining and feeding mine workers. In the 1570s, Villaseca became the founding sponsor of New Spain's Jesuits, providing funds, land, and enslaved Africans to support their mission of Christian education.

The silver boom and the reconstruction it drove shaped the Jesuits' participation in the economy of New Spain. When mining rose at Taxco and Pachuca from the 1550s, the challenge was labor. As native people died and focused on cultivation in communities retaining ample lands, enslaved Africans were bought to serve at mining centers. At least 348 labored at Pachuca in 1556; Villaseca held sixty-eight, more than any other operator. But Africans were expensive, and too valuable as working capital to risk in tunnels or refining with poisonous mercury. Their numbers at Pachuca fell to 186 by 1569 , far outnumbered by 1,163 indigenous naboríos, free workers who demanded cash advances, high wages, and food rations to take on the dangerous labor of driving mines deep underground. In the 1570s, crown authorities tried to revive the native labor draft (relabeled the repartimiento), assigning 1,108 villagers to work in weekly turns in support of mining at Pachuca. Depopulation and community resistance cut the number to 692 in 158 o, then 390 in 1597 - when only 109 enslaved African still served at Pachuca, far outnumbered by 1,168 free, native, and negotiating naboríos. By 1605 , only seventy-three slaves remained, while 950 naboríos risked life to make silver. Meanwhile, 744 people reported as Spanish, most born in New Spain, took on technical, commercial, transport, and other work in support of mining, including many women active in local markets. A parallel pattern emerged at Taxco, where more than six hundred Africans labored as slaves to 158 o, a number that fell to 266 by 1597 , when 804 naboríos labored, backed by 404 drafted villagers. ${ }^{20}$

The turn from reliance on enslaved Africans and drafted Mesoamericans to dependence on paid native naboríos in the mines around Mexico City came amid a larger social reconstruction. From 1550 to 1620 , congregations sanctioned by the crown and implemented by rural friars, drew surviving natives into indigenous republics, head towns and nearby villages granted self-rule, access to regime justice, and lands sufficient to sustain radically diminished numbers. By the late sixteenth century, the native survivors of depopulation

20 This analysis reflects the pivotal research of Gilda Cubillo Moreno, Los dominios de la plata: El precio del auge, el peso del poder; Los reales de minas de Pachuca y Zimapán, 1552-1620, 2nd ed. (Mexico City: Instituto Nacional de Antropología e Historia, 20o6), synthesized in Tutino, Mexican Heartland. 
settled into new lives on the land. While notables might produce maize and more for mining centers and Mexico City markets, the indigenous majority focused on family sustenance and local markets. The survivors of the depopulation showed little interest in laboring in the new world of silver capitalism-except on their own terms.

How, then, to feed that new commercial world? In the wake of the congregations, the regime granted vacated lands to Spaniards ready to build estates to supply Mexico City and the mines with European produce - wheat, sugar, and livestock. Villaseca, the Jesuits' founding benefactor, took the lead on the lands between the capital and the Pachuca mines. As villagers focused on sustaining families and communities, a new commercial economy rose, driven by silver and stimulating commercial cultivation. ${ }^{21}$ For those seeking profit in silver and commercial cropping, the challenge remained labor.

Jesuits arrived in 1572 to face the promise of mining, the rise of commercial cultivation, and the challenge of labor-an unfolding reality parallel to the mix of promise and challenge faced by their colleagues in the developing sugar plantation world of Brazil. But New Spain's silver capitalism rose in very different geographic, economic, and social contexts, calling forth distinct social relations of production - even as both drew on the labors of enslaved Africans. And in both, Jesuits adapted to prevailing economic ways to fund education promoting Christian lives among European elites, native communities, and enslaved Africans, too.

\section{Jesuit Foundations, Economic Participations, and Labor Relations in Early Silver Capitalism}

Pedro Sánchez (d.16oo) led the first Jesuits, eight priests and seven brothers, to Mexico City in 1572 . The goal was to build a college offering the best in education to the sons of prosperous Hispanic and indigenous families: the Colegio Máximo de San Pedro y San Pablo offered preparation for clerical and professional roles. In the 158 os, they founded the Colegio de San Gregorio to educate the sons of indigenous nobles. Later the same decade, the Colegio at Tepotzotlán, north of the city, mixed education for Jesuit scholastics and the sons of native leaders; in time it would train Jesuits for work in Manila and Asia beyond. Once established in the capital, the Jesuits built colegios in provincial capitals at Puebla, Guadalajara, and Oaxaca, the commercial hub at Querétaro, and the northern mining center of Zacatecas.

21 The reconstruction is analyzed in Tutino, Mexican Heartland, Chapter 2. 
The plan to provide Christian education for Hispanic and native elites required economic resources. Prevailing wisdom in Europe preferred funding by urban real estate or censos, crown-backed debt instruments; both promised secure income with little managerial engagement. Neither looked promising in New Spain. So Sánchez sought patrons, advice, and funds. Viceroy don Martín Enríquez (d.16oo) offered advice and patronage; Alonso de Villaseca offered advice, patronage, and endowments derived from decades of mining and estate building.

Villaseca knew that commercial estates brought secure returns without the risks of mining and overseas trade. From 1572 until his death in 1580, he provided 125,000 pesos to fund the Jesuits' purchase of city real estate to build San Pedro y San Pablo, and to buy established estates and additional lands northeast of the capital on the road to the Pachuca mines. Sánchez's Jesuit superiors in Europe and some confrères in New Spain worried about operating estates for profit; debates over gain and the corrosion of community still raged in Europe. Villaseca's vision and funds carried the day, setting the Jesuits at the center of New Spain's commercial economy. The key purchase was Santa Lucía, an estate that came with eight enslaved Africans. There seems to have been no debate about their inclusion. From the 1570s, New Spain's Jesuits funded their colleges by employing paid laborers and enslaved Africans in pursuits of profit to sustain Christian education. ${ }^{22}$

During the silver boom that continued to 1640 , Santa Lucía developed into a complex of estates that mixed wheat production and extensive stock grazing, mostly sheep for mutton and wool, some goats and cattle, too. It added an obraje, a workshop where wool was made into cloth. Diverse workers attended to equally diverse production. Supervision and skilled tasks such as carpentry and smithing fell to sirvientes, permanent Hispanic employees, often of mixed ancestry, who gained monthly salaries and weekly food rations. Continuing purchases of enslaved Africans kept about one hundred bound men, women, and children at Santa Lucía through the seventeenth century. Many enslaved women worked in the obraje; enclosure facilitated social control. Many bound men found greater independence caring for livestock in dispersed pastures. What kept them in bondage? Security of sustenance and attachments to women and children at Santa Lucía mattered. Slavery could not be pure coercion in a complex commercial society where bound Africans lived and worked

22 All this is detailed in Herman Konrad, A Jesuit Hacienda in Colonial Mexico: Santa Lucía, $1576-1767$ (Stanford, CA: Stanford University Press, 1980), a key study that reveals the successful operation of an extensive collection of estates during most of two centuries. 
among diverse peoples including free Hispanic employees and native villagers living nearby in self-governing landed communities.

That complexity shaped labor relations at Santa Lucía. In addition to the permanent work of sirvientes and slaves, Santa Lucía and its outlying estates included gañanes, resident native families granted small plots of land for sustenance and expected to labor for day wages when needed. The most numerous workers in the seventeenth-century hacienda economy were villagers drawn from neighboring landed republics. They raised sustenance on community lands and took wages to plant and harvest estate crops, contracted in crews organized by village leaders. Enslaved Africans remained pivotal but not predominant workers at Santa Lucía into the seventeenth century. The mix of salaried Hispanic employees, enslaved Africans, resident gañanes, and indigenous villagers contracted seasonally brought Santa Lucía the flexibility to profit in changing times. ${ }^{23}$

In 1639, as the first silver boom waned, the Jesuits of San Pedro y San Pablo bought the Xochimancas sugar estate, south of the capital in the Cuernavaca basin, where Cortes heirs and others planted and processed cane-not for export, but to sell in Mexico City. An inventory from 1653 shows 240 slaves: 124 male and 116 female, 174 adults and 73 children. Among the 174 adults, one hundred were born in Africa-including twenty-eight recent arrivals likely purchased by the Jesuits. Of sixty-eight criollo (American-born) adults, nine were born on the estate, twenty-eight were de México (from the city), the rest drawn from across New Spain and Spanish America. Among eighty married couples only thirty-nine reported children. The twenty-three boys and twenty girls five and younger suggest reasonable natural reproduction in recent years; the mere fifteen boys from six to twenty suggests many had been sold away—or fled. The twenty-six girls in the same stage of life were valued for their reproductive capacity—and guarded carefully.

Twenty enslaved adult men were listed with skilled and supervisory roles: carpenters, smiths, irrigators, and herdsmen - as well as overseers and sugar masters. The rest, including many adult women, faced hard tasks laboring in fields and the refinery. Still, slaves remained a minority focused on tasks requiring year-round effort. The seasonal demands of planting, cutting, and hauling cane fell to the larger numbers drawn from nearby indigenous republics, paid cash, and returning home to raise maize and sustain families. As at the Cortes estate and mill, at Xochimancas the Jesuits relied on

23 This synthesizes research presented in Konrad, Jesuit Hacienda, set in context of the analysis in Tutino, Mexican Heartland, Chapter 2. 
enslaved Africans for key skills and regular work-and on landed villagers for field labor. ${ }^{24}$

By the middle of the seventeenth century, Jesuits produced sugar and owned slaves in Portuguese Brazil and Spanish America. In Brazil, the foundational Atlantic plantation society, Africans became and long remained the primary labor force. In New Spain's silver capitalism, slaves labored in a more complex system of production and labor relations in which mining drove an urbanizing society sustained by estates and indigenous communities, and where complex labor relations included Hispanic, mixed, and native peoples—and enslaved Africans.

Brazil's plantation economy proved so profitable that while the Portuguese held primacy in and around the city of Salvador and the Bay of All Saints, Dutch invaders occupied the northeast around Pernambuco from 1630 to 1654 . They learned the business of sugar and slavery, and when expelled took both to the Caribbean. The Catholic Portuguese and the Protestant Dutch depended on enslaved Africans to make sugar and profits as they founded and expanded a pivotal sector of Atlantic capitalism. Built first in Portuguese Brazil with Jesuit participations, plantation capitalism would develop and flourish across Atlantic America, stimulating expanding trade in enslaved Africans.

In Spanish America, silver capitalism boomed from 1570 to 1640, led by the great Andean silver city of Potosí. The Mesoamerican heartland around Mexico City and the new commercial societies that developed around Guanajuato in the Bajío and regions north contributed powerfully, too. The three regions of silver capitalism developed distinct social ways built on differing geographies and local indigenous legacies. All drew meaningful populations of enslaved Africans - the trade facilitated by the union of the Spanish and Portuguese crowns from 1580 to 1640.

In the Andes, bound Africans labored in crafts and transport in the silver city of Potosí and the capital at Lima; they were also drawn to work in emerging plantations along the Pacific coast. ${ }^{25}$ Across New Spain, they faced very diverse roles, demanding regional, even local analysis. Along the gulf coast, enslaved Africans were essential to sugar production. ${ }^{26}$ In the Bajío, they held

24 The data on Xochimancas is in Konrad, Jesuit Hacienda, 247-5o. For comparison, see Barrett, Sugar Hacienda, and for wider context, Cheryl Martin, Rural Society in Colonial Morelos (Albuquerque: University of New Mexico Press, 1985).

25 See Frederick Bowser, The African Slave in Colonial Peru, 1524-1650 (Stanford, CA: Stanford University Press, 1974), complemented by the works of Nicholas Cushner cited in note 7 .

26 See Patrick Carroll, Blacks in Colonial Veracruz: Race, Ethnicity, and Regional Development, rev. ed. (Austin: University of Texas Press, 20o1) and Antonio García de León, Tierra adentro, mar en fuera: El Puerto de Veracruz y su litoral a Sotavento, 1519-1821 (Mexico City: Fondo de Cultura Económica, 2011). 
diverse roles in cities and on commercial estates. ${ }^{27}$ In both regions, men found routes to freedom and came to serve in mulatto militias. ${ }^{28}$

In the heartland around Mexico City, where Jesuits concentrated their economic and educational activities, lives and labors differed still. In the capital, enslaved women and men faced service in wealthy households, artisan workshops, retail shops, construction, transport, and more. ${ }^{29}$ In the hot country around Cuernavaca just south, sugar estates used enslaved Africans for skilled and permanent labor, relying on nearby villagers for planting and harvesting. ${ }^{30}$ Outside the sugar zones, enslaved Africans were less numerous, yet present everywhere.

Still, for all the varying ways enslaved Africans sustained silver capitalism across New Spain, one social reality was shared. Everywhere, enslaved Africans were a pivotal minority living and working among indigenous majorities. Those arriving in bondage were mostly men, taken captive in Africa's wars. ${ }^{31}$ They lived and worked among native majorities that were gender balanced-and the offspring indigenous women were free under Spanish law. In that context, enslaved African men repeatedly, and by all indications purposefully, fathered children with native women - some residents of the same estate, some living in nearby communities, some neighbors in cities and towns.

The result, evident by the mid-seventeenth century, was a proliferation of free mulattos who often took on the same labors done by enslaved fathers, sometimes moved north to the opening world of mining and commercial grazing, and where they could join mulatto militias. Free mulattas might remain with their mothers, some founding families at estates, others living in indigenous communities. By diverse relationships, enslaved African men and free native women made generations of free mulattos/as who joined in the commercial dynamics of New Spain in diverse ways. In the long run, they limited the demand for enslaved producers. ${ }^{32}$ The reproductive path to freedom was

27 This is the focus of the pivotally important work by María Guevara Sangines, Guanajuato diverso: Sabores y sinsabores de su ser diverso (Guanajuato: Ediciones La Rana, 2001).

28 See Ben Vinson, Bearing Arms for His Majesty: The Free Colored Militias in Colonial Mexico (Stanford, CA: Stanford University Press, 2001).

29 María Elisa Velázquez Gutiérrez, Las mujeres de origen africana en la capital novohispana (Mexico City: Universidad Nacional Autónoma de México, 2006).

30 See Barrett, Sugar Hacienda; Martin, Rural Society; and Gisela von Wobeser, La hacienda azucarera en la época colonial (Mexico City: Universidad Nacional Autónoma de México, 1988).

31 On slavery and the slave trades in Africa, see Paul Lovejoy, Transformations in Slavery: A History of Slavery in Africa (New York: Cambridge University Press, 2012).

32 Much of this diversity is detailed in Guevara Sangines, Guanajuato diverso; Velázquez Gutiérrez, Mujeres de origen africana; Tutino, Making a New World; and García de León, Tierra adentro, mar en fuera. 
a distinct characteristic of New Spain, worrisome to slaveowners, including Jesuits, liberating to many children of the enslaved.

\section{$4 \quad$ Eighteenth-Century Expansions and Negotiations}

As the eighteenth century opened, the silver and sugar economies that were American engines of global trade revived, with important regional shifts. The Brazilian northeast, the founding center of plantation capitalism, ceded leadership to the British and French Caribbean, where production by enslaved workers soared to new heights. ${ }^{33}$ Brazil revealed its entrenched reliance on enslaved Africans when gold mining rose in Minas Gerais, inland from Rio de Janeiro. ${ }^{34}$ Andean Potosí proved slow to recover from the mining decline after 1640. Meanwhile, New Spain's heartland, Bajío, and regions north rose to global leadership after $1700 .{ }^{35}$ As silver capitalism soared in New Spain, Jesuits remained leading educators, estate operators, and slaveowners-until the expulsion of 1767 .

Silver production doubled in New Spain from 1700 to 1750 , then plateaued (to double again from 1770 to 1810 in a world without Jesuits). Renewed production at Taxco and Real del Monte (above Pachuca) near Mexico City combined with unprecedented output at Guanajuato in the Bajío and Zacatecas and other centers to the north. New Spain's silver drove soaring trades with China, India, Europe, and the worlds between. Commercial cultivation expanded around Mexico City, in the Bajio, and regions north. ${ }^{36}$

Jesuits remained key participants—before the expulsion. Established colegios in Mexico City, Querétaro, Zacatecas, and elsewhere remained leaders in education. As Guanajuato rose to become the world's primary center of silver production, local elites sought a Jesuit presence. From the 173os, they worked to found a new colegio. Doña Josefa Theresa de Busto y Moya (1682-1742), widow of a merchant financier, sister of leading mine operators, and owner of rich estates, led the effort. She pledged sixty thousand pesos (a fifth of her wealth) and recruited another fifteen thousand from others-much less than the 125, 000 pesos Villaseca gave the Mexico City Jesuits in the 1570s. To complete

33 The classic study is Richard Dunn, Sugar and Slaves: The Rise of the Planter Class in the English West Indies, 1624-1713 (Chapel Hill: University of North Carolina Press, 1972).

34 See Kathleen Higgins, "Licentious Liberty" in a Brazilian Gold-Mining Region: Slavery, Gender, and Social Control in Eighteenth-Century Sabará, Minas Gerais (State College: Penn State University Press, 2007).

35 See Lane, Potosi, Chapters 6-7 on the once pre-eminent city's eighteenth century.

36 See Tutino, Mexican Heartland, Chapter 3, and Making a New World, Chapters 3-4. 
funding, mine operators devised an ingenious plan: as workers left the mines, they were required to "donate" a portion of the ore shares they kept as an incentive beyond wages. In the end, worker "contributions" exceeded the endowments of the powerful in funding the new Jesuit presence in Guanajuato. ${ }^{37}$

That funding is notable given the goals proclaimed by those calling the Jesuits to Guanajuato. A colegio would educate sons of the rich, the prosperous, and the aspiring in the professions - in service of the mines, the regime, and the church. In addition, Jesuits were to provide "missions" to pacify unruly mine workers, most free mulattoes of Afro-indigenous origins. Mine operators and clergy saw mine workers as disruptive, often criminal, and lacking Christian commitments to work in the world-and to save their souls in the next. Guanajuato mine workers would pay for their own pacification.

While construction proceeded, Jesuits led urban missions calling workers to penance and devotion. The city calmed for a time, then returned to boisterous, unruly ways. Mining boomed; the work carried on. The colegio opened in $1765 .{ }^{38}$ In 1767 , the expulsion decree came to Guanajuato amid riots resisting crown taxes and other demands. When riotous workers offered to protect Jesuits who earlier had tried to pacify them, the Jesuits surrendered to expulsion rather than join the crowds. ${ }^{39}$

Further north, the eighteenth century saw Jesuits expand their roles as missionaries among independent native peoples, parallel to the order's famous role among the Guaraní in South America. The Yaqui cultivated rich river valleys along the Sonora coast. The northward thrust of silver after 1700 saw Yaqui men living under Jesuit oversight trek on long circuits to labor at mines and grazing estates, returning sooner or later to reinforce home communities. ${ }^{40}$ Other Jesuits, funded by the Bajío mining boom, founded the first missions in Baja California. ${ }^{41}$

In Mexico City, the Colegio de San Pedro y San Pablo continued to offer education to Spanish (mostly American-born) elites, the Colegio de San Gregorio

37 The northward boom is detailed in Tutino, Making a New World, Chapter 3.

38 This is detailed in Tutino, Making a New World, 179-82, based on original documents published in Isauro Rionda Arreguín, La Compañía de Jesús en la provincia guanajuatense, 1590-1767 (Guanajuato: Universidad de Guanajuato, 1996).

39 See Tutino, Making a New World, Chapter 4, and Felipe Castro Gutiérrez, Nueva ley y nuevo rey: Reformas borbónicas y rebelión popular en Nueva España (Zamora: Colegio de Michoacán, 1996).

40 See Cynthia Radding, Wandering Peoples: Colonialism, Ethnic Spaces, and Ecological Frontiers in Northwestern Mexico, 1700-1850 (Durham, NC: Duke University Press, 1997) and Raphael Folsom, The Yaquis and the Empire: Spanish Imperial Power and Native Resilience in Colonial Mexico (New Haven, CT: Yale University Press, 2014).

41 Tutino, Making a New World, 118. 
still drew sons of native notables, and the colegio at Tepozotlán trained Jesuits to work in Manila and Asia beyond. While New Spain's silver drove northward expansion and rising global trades, Mexico City's Jesuits adapted to sustain their colleges and missions.

With silver soaring, Mexico City grew as the center of regime rule, church activities, craft production, global trades, and the financial integration of everything. Meanwhile, as natives gained immunities, population rose in surrounding indigenous republics, often doubling from the late 1600 s to the mid170os. Growing numbers of villagers consumed more of their own produce just as growing urban and mining centers demanded increased food supplies. As native growers ceased supplying urban markets, commercial estates turned to planting native staples.

Mexico City Jesuits saw opportunities. Soon after 1700, they bought San José Chalco, a wheat property they planted in maize to feed the capital. Relying on a core of Hispanic employees and vast crews of local villagers to plant and harvest, San José Chalco held few if any slaves. In a wider turn to commercializing native products for urban markets, the Santa Lucía complex began to produce and market pulque - the native fermented drink popular in city taverns and mining saloons. Pastures long used for grazing were covered with maguey cactus. Transplanting drew great gangs of villagers to months of hard labor; then the maguey matured for five years - to be tapped and fermented into pulque by crews of one or two native men. The turn to pulque, too, came without reliance of enslaved workers. ${ }^{42}$

Still, Santa Lucía retained 312 slaves around 1740: 161 males and 151 females. Gender balance contributed to a growing population: ninety-eight males and seventy-two females were twenty or younger-fifty-five percent. Were boys retained for future labor while girls were sold away, perhaps to urban household service? What is clear is that a large enslaved population remained, with a limited number of working adults. Only seventy (twenty-three percent) were in their twenties, and gender balanced; a mere thirty-two were in their thirties, and mostly female, as were the forty who were older. In the 1740s, Santa Lucía retained a large population of enslaved people, yet enslaved workers were few.

They lived in family groups: forty-three households of two parents plus their children totaled 194 people; single parent households with children totaled fifty-one more; thirteen married couples without children brought another twenty-six - bringing a total of 271; eighty-seven percent of the bound lived in family units. That pleased the Jesuits; the dearth of workers did not. Four enslaved women had married free men, their children thus enslaved. Seven

42 See Tutino, Mexican Heartland, Chapter 3. 
enslaved men had married free women-freeing their children, denying human property to the Jesuits. ${ }^{43}$

Lists of enslaved people from $175^{\circ}-5^{1}$ at three properties, Santa Lucía, Provincia, a grazing center near Guadalajara to the northwest, and Xalmolonga, a sugar estate in lowlands south near Taxco, reveal populations ever less available for labor-except for sugar. At Santa Lucía, enslaved women outnumbered men 115 to 106, with but twenty-five men of prime laboring age between twenty-one and forty; thirty-seven women from sixteen to thirty were of prime reproducing age. The largest numbers were the fifty-seven boys and forty-seven girls ages fifteen and under. Adults provided a variety of services, some still making cloth in the obraje, others set to diverse tasks-but enslaved workers were no longer central to Santa Lucía's production or profitability.

At Provincia, among the ninety-three enslaved, about twenty-five young adult men cared for livestock; forty-two boys and girls were fifteen or under; the rest were aging adults from forty to seventy-five- - with women preponderant among the oldest. Most of the enslaved at Santa Lucía and Provincia were children or aging adults living on estate resources. Notably, the Jesuits did not free the elderly to avoid costs of sustenance and care. They kept large enslaved populations that provided minimal labor service-and included many children who might be sent or sold to other enterprises in need of labor.

At Xalmolonga, enslaved adults, men and women, remained central to sugar production. Among 253 slaves living there, sixty-one men were of prime working age, sixteen to forty, joined by an equal number of women in the same ages: 122 of 253 were available to labor. All were born in New Spain, most lived in family units, and they had one hundred children fifteen and under. They might sustain sugar for a foreseeable future-perhaps joined by enslaved children sent from Santa Lucía. Slavery receded broadly across New Spain in the mid-eighteenth century as growing numbers of Hispanic employees and village hands became available. Still, sugar growers remained committed to enslaved labor, as evident at the Jesuits' Xalmolonga. ${ }^{44}$

When Jesuits faced expulsion from Spain's empire in 1767 (for political reasons little connected to New Spain) enslaved workers were of little import to cereal and grazing estates-yet still essential at Xalmolonga. The enslaved

43 The demographic details are from Konrad, Jesuit Hacienda, 254-57. For an unparalleled account of how enslaved people in the eighteenth-century Bajío worked to free their children — enslaved men seeking relations with free, often indigenous women; enslaved women giving up babies for undocumented "adoptions" to avoid bringing them to lives of bondage - see Guevara Sanginés, Guanajuato diverso.

This is my interpretation of data reported in Konrad, Santa Lucía, 262-66. 
population there had grown to 371, many likely drawn from Santa Lucía. Under crown management, they were reported as recalcitrant and disinclined to labor. Had newcomers forced to the lowlands and lives of hard labor in the cane fueled new resistance? Did the end of Jesuit management contribute too? We cannot know.

The oft-noted affinity between sugar and slavery held strong in eighteenth-century New Spain. Growers of maize and wheat, pulque and livestock learned that greater profit came by negotiating with paid workers, Hispanic, mixed, and indigenous, some permanent, many seasonal. Slavery endured because sugar remained an important source of profit. The hard, often maiming work of sugar led growers to keep enslaved workers, in New Spain and across plantation America.

The maiming that came with sugar labor is clear in the Jesuit Giovanni Antonio Andreoni's (João Antonio Antonil, 1649-1716) Cultura e opulência do Brasil por sus drogas e minas (Culture and opulence of Brazil due to its drugs and mines [Lisbon, 1711]), written at the opening of the eighteenth century. He detailed the brutality of sugar labor among enslaved men and women. ${ }^{45}$ Yet we know that Brazilian planters, including Jesuits, learned that while coercion defined slavery, profitable production required limited incentives within bondage: chances to become supervisors or skilled workers, access to plots for family use, days to socialize, etc. ${ }^{46}$ Such negotiations were also central to Jesuit management in eighteenth-century New Spain, perhaps more central as slaves lived and worked in a society of social diversity and ongoing negotiations of production and labor.

The negotiation of production and labor during New Spain's eighteenth-century silver boom, with an emphasis on dealing with slaves, is opened to view in a unique Jesuit text: the Instrucciones a los hermanos jesuitas administradores de haciendas (Instructions for Jesuit brothers managing estates). No author's name or date marked the manuscript found in Mexican archives (among documents claimed after the expulsion). Careful analysis by the French historian,

45 We now have an English version: João Antonio Antonil, Brazil at the Dawn of the Eighteenth Century, ed. and trans. Timothy Coates, Preface by Stuart Schwartz (Dartmouth: Tagus Press at the University of Massachusetts Dartmouth, 2012). On the predominance and negotiations of slavery in the gold regions, see Kathleen Higgins, "Licentious Liberty."

46 This is a key emphasis of Schwartz, Sugar Plantations. 
François Chevalier (1914-2012), indicates a text produced in the second quarter of the eighteenth century, as silver capitalism boomed and production at Santa Lucía and other estates surged. Written by Jesuit superiors for Jesuit managers, the manual reveals a fusion of profit seeking and religious commitments. The absence of clear authorship and the inclusion of references from the late sixteenth to the early eighteenth century raises an intriguing possibility: were the Instructions maintained as an evolving guide, first drafted in the era of estate building, then revised over decades to address changing times? Such an evolution would explain some contradictions in the eighteenth-century text-and make it an expression of evolving Jesuit thinking. ${ }^{47}$

The text opens insisting that Jesuit brothers who managed estates "must show lives of true religious spirit." In urban colegios, community life obliges "even the most distracted to live outwardly as a man of religion." At rural estates, managing brothers faced liberties "surrounded by the devil, temptations of the flesh, idleness, work with lay people [...] all weakening fervor, distracting the spirit, diminishing the fear of God, and relaxing the conscience." To limit temptations, regular devotions were essential—and women should never live in the manager's residence. ${ }^{48}$

Central to a life simultaneously religious and managerial, after recording each day's work and instructing overseers on plans for the next, the Jesuit manager should "assemble in the chapel all the free employees who live at the estate, and also all the slaves" to join the rosary and other devotions. The goal of linking production, labor, and devotion was clear. ${ }^{49}$ To gain "blessings in the fields and the harvests of the hacienda, it is necessary to give greater care to the souls and education of the employees and residents than to cultivating the fields; God promises abundant harvests of worldly fruits to those who keep his Holy Law." 50

Still, the Instructions emphasized that estate residents "recognize no master beyond he who delivers food." How to integrate religion, work, and material lives? Constant preaching, prayer, and oversight: all estate residents must attend Mass on Sundays and festival days; records would be kept of the religious lives of native gañanes, their wives and children; those missing Mass without "rational excuse" would face to six to eight lashes by the fiscal, a native religious assistant, before Mass the next Sunday. Enslaved residents who failed

47 The full text was published in IHJ. In his prologue, Chevalier identified references and dated the work to the second quarter of the eighteenth century. The suggestion of an evolving text with multiple Jesuit authors is mine.

48 IHJ, 35-47; quotes, 35-36; the restrictions on access to women, $42-43$.

$49 \mathrm{IHJ}, 40$.

5O IHJ, 49 . 
to attend Mass would face the same discipline. ${ }^{51}$ Was the linkage of native dependents and slaves a remnant of sixteenth-century thinking, leaving both subject to physical coercion? That option rarely reappears in the longer text.

The eighteenth-century text repeatedly laments that workers, free and enslaved, refused to live exemplary lives; it offered advice on how to reform or constrain independent dependents. Jesuits managers must take care that "estate sirvientes and gañanes" avoid "drunkenness and disputes, hatreds and scandals" - which must be corrected quickly. "The hacienda should not accept employees of disrepute and disruptive lives." Still, recognizing reality, when such people were admitted, they would be admonished twice; if they continued, they would be expelled — and paid for work done. ${ }^{52}$ Recruiting Hispanic employees who met Jesuit standards was not easy-nor was the control of those who came. Yet whoever came must be paid, whatever their transgressions, or few would follow.

Indigenous people seeking residence, work, and the means to eat must be examined carefully: men arriving "to live at the hacienda with women" too often were "couples feigning marriage." They should be sent to marry-or expelled. "Others arrive having fled estates while owing advances, even changing names to avoid discovery." Such debtors in disguise might be taken on, but should gain "nothing in advance, so they cannot repeat the offense-and so that if a former employer finds them, they leave owing nothing to us." ${ }^{\prime 53}$ Life and labor were ongoing negotiations between Jesuits and diverse workers.

The management- "buen gobierno" — of the enslaved was no easier. A long chapter focused on that challenge. It began stating that everything already said about the religious and working lives of free Hispanic and indigenous workers applied to slaves, too. It said nothing about buying, selling, or moving slaves, avoiding the topic of the break-up of families when people were sold or moved from Santa Lucía to a sugar property like Xalmolonga. The focus was on slave life, worship, and work.

Slaves should live in huts assembled in a compound called a real, surrounded by a fence with but one gate, visible to the manager's house. The coming and going of the enslaved would be watched and blocked by locking the gate at night. Primary oversight depended on enslaved overseers: "A faithful slave of good judgement and mature age should be named mandador (commander). He would deliver orders for all work and serve as overseer in the

\footnotetext{
$5^{1} \quad$ IHJ, $5^{2-53}$.

$5^{2} \mathrm{IHJ}, 56$.

$53 \mathrm{IHJ}, 57$.
} 
fields." He must prevent disturbances and impose remedies. ${ }^{54}$ In addition, "an enslaved woman of wisdom and maturity should be appointed mandadora of women slaves; she must always accompany them in their work and ensure there are no quarrels, disputes, or dissentions." Only a mandador would correct enslaved men, only a mandadora would correct enslaved women. Free overseers would never correct enslaved men or women; "Such impositions lead to grave difficulties." 55

The Instructions insisted that Jesuit managers act "with great calm and moderation in punishing offenders. Do not act with excess rigor, which accomplishes nothing and leaves the subject to live in discontent, working only when forced, and accomplishing little." Better to act "as fathers." Do not be quick to resort to "bars, chains, and stocks"; if slaves must be contained, "be sure the time is limited." Better that offending slaves learn the gravity of their errors, be allowed to beg for pardon, then offered "liberty" to return to their huts and labors-knowing that great punishment will come with any recurrence. 56

Every list of slaves noted runaways. The Instruction stated: "be generous welcoming back fugitives who recognize their error and ask forgiveness and mercy, especially if an honorable godfather pleads their acceptance." Otherwise, "slaves seeing no gain in humility or patronage, once having fled will never return, $[\ldots]$ they will live as thieves at the cost of the estate." ${ }^{57}$ Forgiveness enabled the retention of laboring property.

So did the provision of clothing and staple foods. "Once each year [...] deliver new clothes, hats, and blankets to all the slaves." Material should be ordered in advance and a tailor brought to the estate to cut and sew clothing. As families received clothing, the mandador/a must insist that the new outfits be worn at fiestas, "to prevent the sale of new clothing, as many do, to then live in rags the coming year." 58

The means to eat underlay everything. "Deliver necessary sustenance weekly to the slaves, providing rations of maize, meat, salt, chile, tobacco, and a bit of honey when available." For meatless days, deliver "fish or beans." To ensure fair distribution, "the administrator will join the overseer, mandador, and the slaves to measure and distribute meat on Saturday afternoon; maize on Sunday morning; Friday rations on Thursdays," recording all "by the number

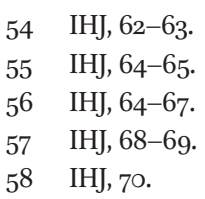


of persons in each family, adults and children." Additional distributions of food and clothing came at marriages, births, and baptisms, and at Christmas, too. ${ }^{59}$

"Take great care with the ill." On the first sign of illness, enslaved residents should be moved to an infirmary to receive care-and ensure no feigning to avoid work. "Designate an elder enslaved woman, wise in everyday cures, as a nurse, and be sure others learn at her side," ready to assist when disease spreads. A literate employee should share cures from a Jesuit medical manual; the estate would provide "common ordinary medicines." Also essential: "an intelligent midwife." She too should train assistants to help and carry on in the future. Midwives would be trained to call the priest should death appear imminent, and to baptize if there was no time to wait. ${ }^{60}$ Care for the soul, for the health of the workforce, and for the preservation of human property were inseparable — and assigned to enslaved women.

Labor was the goal. "Enslaved children must not be idle. Set them to work from eight years of age, assigning tasks appropriate to their strength." An "old slave woman" should assemble them each morning, separating boys and girls to recite Christian doctrine and attend Mass. "Afterwards, the slave woman will lead them to the fields to work clearing rocks, cleaning paths, moving refuse, and similar tasks." At the end of the day, "the children will return with their mothers to the real." Younger children should also contribute: "Small children from five to eight" would go to the fields "to carry nursing babies while their mothers work." Clearly, new mothers gained no rest. As to infants, once weaned, "The smallest, not yet five years old, will stay at home while their mothers go to the fields, given to the care of another elder slave woman, retired from labor, who will teach prayers and the sign of the cross." ${ }^{\text {61 }}$

Enslaved girls passing puberty gained close attention: "Because grave problems always result when unmarried girls find independence, [...] all twelve and older will be gathered in a home, separate from the real, which will serve as a colegio de doncellas [school for unmarried girls] to live until they marry. To preserve their honesty [chastity?], a widowed and wise slave woman will serve as mistress, taking them to the fields, working with them, caring for them in all things - and reporting any disorder to the administrator." 62 Keeping reproduction within sacramentally sanctioned marriages was a key Jesuit goal; so was keeping enslaved women at work before and after marriage and childbirth.

$\begin{array}{ll}59 & \text { IHJ, 71-73. } \\ 6 \text { o } & \text { IHJ, 74-76. } \\ 61 & \text { IHJ, 76-78. } \\ 62 & \text { IHJ, 78-79. }\end{array}$ 
The Jesuits aimed to keep slaves away from surrounding communities: "Do not allow [...] slaves to visit nearby pueblos, even on festival days, as thefts, drunkenness, and other wrongs always happen; do not allow natives, traders, performers, or other outsiders to enter the slaves' real, as grave problems always follow." ${ }^{\prime 3}$ Encounters with the world outside the estates would disrupt good order, limit Jesuit oversight, facilitate escapes, and introduce enslaved men to indigenous women. Reproduction with the latter would free children-capital and labor lost to the Jesuits.

Despite such oversight, "Never have confidence in slaves, however good and faithful they appear; do not trust them with the keys to granaries or estate stores - the opportunity makes them thieves; the most faithful slaves become unfaithful if trusted too much. To keep all slaves faithful, always watch them closely, so the unfaithful will not steal, so the faithful will not become unfaithful in the face of opportunity." 64 To inhibit theft, managers should be ready "to give the most hardworking and faithful slaves [...] small gifts [...] of coin or everyday things they may need." 65 Incentives and rewards were essential to keeping enslaved people, presumed untrustworthy, at work and at prayer.

A final dilemma. After prescribing the necessity of enslaved men serving as mandadores and enslaved women serving as mandadoras, nurses, midwives, and care providers, the Instructions warned, "Do not trust slaves with roles of too much liberty, because they ordinarily abuse such trust when alone as overseers, assistants, stewards, cane guards, pasture overseers and in other roles that bring life mounted on horseback, [...] beyond taking liberties, they become facilitators of other slaves' thefts and other evils." ${ }^{n 6}$ Dependent on enslaved men and women for oversight and mediation, the Jesuits knew that overseers and others with liberty and responsibility would serve the enslaved community when they could.

The only way through a world of contradictions shaped by Jesuit profit-seeking and enslaved people's pursuit of sustenance and independent lives: Christian commitments. The chapter on slave management concludes: "Make slaves good Christians and you will make them good sirvientes [using the term normally given free Hispanic employees] —and God will shower them with all his blessings." ${ }^{\prime 7}$ After documenting that keeping enslaved workers required

\footnotetext{
63 IHJ, 79.

64 IHJ, 79-8o.

65 IHJ, 8 o.

66 IHJ, 80-81.

$67 \mathrm{IHJ}, 83$.
} 
constant vigilance and negotiation, the manual concluded that only effective Christianization could make slaves dedicated producers for Jesuit profit.

The Instructions then turned to the complex labor relations that included Hispanic sirvientes, enslaved Afro-Mexicans, resident native gañanes, and crews of workers who came seasonally from landed villages. Negotiations were constant, uncertain, and different with every group. Sirvientes repeatedly asked for advances against work to be done. The Instructions resisted, knew they were necessary, and recommended keeping them minimal, as many left without working off or repaying advances. Native gañanes also pressed for advances, yet rarely left as their plots held them at the estates. Still, advances were rarely covered. Disputes over work and remuneration sometimes escalated into conflicts. Hispanic sirvientes should be admonished twice; if faults persisted, they should be expelled, the advances lost to the estate. When gañanes built debts they could not pay, as natives, they might be "corrected"-yet the Instructions advised moderation, leniency, and recognition that advances would rarely be repaid. Jesuit power proved limited; they could press for obedient service-but recognized the need for negotiated moderation backed by religious cajoling. ${ }^{6}$ The views and goals of working people remain unknown.

Another moderation: In the chapter on sugar production, the first recommendation was not to rush the cutting, milling, and refining of cane. Harvesting and refining only three days per week over many months would limit the dangers and disabilities faced by enslaved workers, preserving them to work longer years. ${ }^{69}$ Another contradiction: the Instructions emphasized that carpenters, smiths, and their assistants, along with those who made the pottery for refining and shipping sugar, should be enslaved men and boys, keeping key skills in the estate community. Yet free employees should rule the final stages of refining. Enslaved people pilfered product for their own use and sales-a problem notable among sugar masters, enslaved and free. ${ }^{70}$ Social control was uncertain in eighteenth-century New Spain, even at sugar estates where a laboring core still lived enslaved. Jesuits knew they had to negotiate more than they could impose.

The Mexico City Jesuits struggled to negotiate life and work with the hundreds of enslaved dependents at the estates that sustained their urban colleges. They reserved the right to coerce, but counseled against it-preferring to promote Christian values, provide solid sustenance, and press for effective service among the enslaved and the diverse free workers equally essential to

$\begin{array}{ll}68 & \text { IHJ, 128-32. } \\ 69 & \text { IHJ, 182. } \\ 70 & \text { IHJ, 186-92. }\end{array}$ 
estate profits. New Spain was unique in the eighteenth-century Americas - for the dynamism of its silver capitalism and the complex social order that sustained it. The labors of favored Hispanic sirvientes, enslaved Afro-descendants, dependent indigenous gañanes, and independent landed villagers were all essential to the Jesuit economy, and the larger estate production that sustained silver capitalism. That complexity made negotiation with diverse producers, including slaves, an everyday necessity.

The need to negotiate to keep enslaved people at work was common across the early Americas - in diverse ways in regions with distinct social orders. In Brazil, enslaved Africans were the primary labor force in the Americas first sugar plantation economy. Bondage marked and marred the lives of many among the skilled and supervisory few, and the great majority of men and women who worked in fields and refineries. They faced regular coercions. Yet estate managers, Jesuits and others, learned that incentives and small liberties were essential to effective production. ${ }^{71}$ When gold mining along surface streams in the interior of southern Brazil became a leading sector after 1700 , enslaved people did the work-in conditions of negotiated openness one leading analyst labelled "licentious liberty."72

The labor of enslaved people was negotiated because slaveowners needed their labor to produce for profit, and because the latter, by their inherent humanity, had enduring needs for survival, family, and community-and worked to claim what they could. Negotiations proved especially complex in New Spain thanks to the complex social order and cultural ways that evolved to sustain and contest silver capitalism. There was no Jesuit exceptionalism in the goal of fusing Christianity, capitalism, slavery. Yet, Jesuits appear exceptionally effective in one critical way. They kept gender balance in their communities of the enslaved, limiting men's ability to join indigenous women and free their offspring. ${ }^{73}$ By ensuring that sacramentally sanctioned families defined life among the enslaved, Mexico City's Jesuits ensured that they remained enslaved deep into the eighteenth century.

Reading the Jesuit Instructions against Jesuit labor accounts suggests a broad acquiescence among the enslaved to a Christian regime of life and work. Yet the Instructions repeatedly lament that the enslaved were unfaithful, ready to pilfer, and in need of constant vigilance-suggesting that few had internalized the culture of Christian capitalism. If only we had an enslaved peoples' guide to adaptation and survival, resistance and escape.

\footnotetext{
71 This is a major conclusion of Stuart Schwartz in his classic study of Sugar Plantations.

72 Kathleen Higgins, "Licentious Liberty."

73 Such challenges are a recurrent theme in Guevara, Guanajuato diverso; Martin, Rural Society in Colonial Morelos; and Tutino, Making a New World and Mexican Heartland.
} 